\title{
Analisis Kebutuhan Pengembangan E-Module Berbasis POE (Predict, Observe, Explain)
}

\author{
Siti Rabiatul Hasanah ${ }^{1),}$, Hadma Yuliani ${ }^{1)}$, Nur Inayah Syar ${ }^{1)}$, Eka Wahyu Nengsih ${ }^{1)}$, Jhelang \\ Annovasho ${ }^{1)}$ \\ ${ }^{1)}$ Program Studi Tadris Fisika, FTIK, Institut Agama Islam Negeri (IAIN) Palangka Raya \\ `sitirabiatulhasanah@gmail.com
}

Abstrak: Penelitian ini bertujuan untuk: 1) mengetahui bahan ajar yang digunakan dalam pembelajaran fisika tidak meningkatkan semangat belajar siswa; 2) mengetahui kebutuhan akan bahan ajar yang disusun; 3) mendeskripsikan kesulitan belajar siswa; 4) Mengetahui kebutuhan pembelajaran fisika yang membuat siswa memprediksi dan mengobservasi suatu fenomena dikehidupan sehari-hari. Penelitian ini termasuk penelitian gabungan antara quantitative research dan qualitative research. Metode pengembangan dalam mengembangkan produk e-module berbasis POE menggunakan model pengembangan 3D, yang terdiri dari tahap define, design, dan development saja. Teknik pengumpulan data yaitu wawancara dengan guru fisika SMA kelas XI, dan angket analisis kebutuhan untuk siswa guna mengetahui permasalah yang dialami siswa terkait bahan ajar fisika. Angket analisis kebutuhan siswa disebarkan secara online melalui google form kepada siswa kelas XI SMA Negeri 5 Palangka Raya. Hasil Penelitian menunjukkan: 1) 52,9\% bahan ajar yang digunakan dalam pembelajaran fisika tidak meningkatkan semangat belajar siswa; 2) 94,1\% siswa menyukai bahan ajar yang disusun karena komunikatif dan memiliki ilustrasi gambar yang menarik; 3) 64,7\% siswa mengalami kesulitan memahami materi teori kinetik gas dengan model pembelajaran digunakan guru saat pembelajaran; 4) 88,2\% siswa menyukai pembelajaran fisika yang membuat siswa memprediksi suatu fenomena dikehidupan sehari-hari dan $84,2 \%$ siswa menyukai pembelajaran yang bersifat mengobservasi suatu fenomena.

Kata Kunci: Analisis kebutuhan, e-module, POE (Predict-Observe-Explain).

\section{Pendahuluan}

Di masa pandemik, seorang guru memiliki kewajiban untuk mengikuti perkembangan teknologi sehingga lebih baik dalam berkomunikasi dan tidak gagap informasi yang sekarang telah berbasis digital agar dapat mengelola, mengevaluasi dan menyajikan proses pembelajaran (Solihudin, Pengembangan E-Modul Berbasis Web untuk Meningkatkan Pencapaian Kompetensi Pengetahuan Fisika pada Materi Listrik Statis dan Dinamis SMA, 2018). Pengembangan keterampilan dalam kegiatan pembelajaran memerlukan suatu bahan ajar (Sidiq \& Najuah, Pengembangan E-Modul Interaktif Berbasis Android pada Mata Kuliah Strategi Belajar Mengajar, 2020). Bahan ajar merupakan suatu sumber belajar terpenting yang harus ada dalam setiap kegiatan pembelajaran (Olayinka, 2016). Karena, bahan ajar berisi rambu-rambu materi yang akan dipelajari (Maslahah \& Rofiah, 2019). Salah satu bentuk bahan ajar yang dapat digunakan ialah modul.

Modul berbentuk cetak cenderung monoton dan kurang menarik (Sidiq \& Najuah, Pengembangan EModul Interaktif Berbasis Android pada Mata Kuliah Strategi Belajar Mengajar, 2020). Pemanfaatan teknologi informasi dan komunikasi digunakan untuk pengembangan bahan ajar modul cetak menjadi modul elektronik (e-module) (Tania \& joni, 2017). Penggunaan e-module dalam pembelajaran memiliki beberapa keunggulan, seperti lebih hemat biaya (Tania \& joni, 2017), materi yang disajikan terdapat gambar, animasi, dan video, membuat proses belajar siswa menjadi lebih menarik dan menyenangkan, serta dengan adanya e-module siswa dapat belajar dengan mandiri tanpa atau dengan bimbingan guru (Varonika, Santyadiputra, \& Sindu, 2016).

Bahan ajar akan menjadi menarik jika dipadukan dengan model pembelajaran yang mampu mendorong siswa untuk memprediksi maupun mengobservasi suatu fenomena dalam kehidupan sehari-hari. Model pembelajaran yang dipilih adalah yang menekankan siswa untuk lebih aktif dalam kegiatan pembelajaran 
(Rahman, 2016), yaitu model POE. Model POE merupakan model pembelajaran yang terdiri dari 3 tahapan kegiatan, yaitu tahap prediksi atau membuat dugaan awal (predict), pengamatan atau pembuktian dugaan (observe), serta penjelasan terhadap hasil pengamatan (explain) (Safitri, Pengaruh Model POE Terhadap Hasil Belajar IPA Fisika Siswa SMP, 2019). Model POE mampu membangkitkan semangat dan rasa ingin tahu siswa, mampu membuat kegiatan pembelajaran menjadi lebih menarik, serta mampu merangsang siswa untuk kreatif terkhusus pada tahap predict (memprediksi) (Yupani, Garminah, \& Mahadewi, 2013). Berdasarkan uraian di atas diharapkan dapat mengetahui bahan ajar yang digunakan dalam pembelajaran fisika tidak meningkatkan semangat belajar siswa, mengetahui kebutuhan akan bahan ajar yang disusun sehingga komunikatif dan memiliki ilustrasi gambar yang menarik, mengetahui kebutuhan pembelajaran fisika yang membuat siswa memprediksi suatu fenomena dikehidupan sehari-hari dan mengobservasi suatu fenomena dan mendeskripsikan kesulitan belajar siswa.

\section{Metode Penelitian}

Penelitian ini termasuk dalam penelitian gabungan antara quantitative research dan qualitative research. Penelitian mix method research merupakan salah satu metode penelitin digunakan jika peneliti mempunyai pertanyaan dan dapat diuji diuji dari luaran serta prosesnya (Masrizal, Mix Method Research, 2012). Jenis penelitian yang dipilih untuk penelitian ini adalah penelitian deskriptif yang merupakan penelitian untuk mendeskripsikan, menggambarkan, mendefinisikan, ataupun melukiskan suatu peristiwa yang terjadi secara realistis, nyata, factual, serta akurat berdasarkan kejadian yang diamati (Mustafa P. S., 2020). Metode pengembangan untuk mengembangkan produk e-module berbasis POE menggunakan model pengembangan 3D, yang terdiri; define, design, development, desiminate, namun dibatasi sampai tahap development saja.

Teknik pengumpulan data pada penelitian ini yaitu wawancara dengan guru fisika SMA kelas XI, dan angket analisis kebutuhan untuk siswa guna mengetahui permasalah dialami siswa terkait bahan ajar digunakan dalam mempelajari materi fisika. Angket analisis kebutuhan siswa disebarkan secara online melaui google form kepada siswa kelas XI SMA Negeri 5 Palangka Raya.

\section{Hasil dan Pembahasan}

Hasil dan pembahasan analisis kebutuhan pengembangan e-modul berbasis POE tertera pada tabel 1.

Tabel 1. Hasil angket kebutuhan siswa

\begin{tabular}{|c|c|c|c|c|c|}
\hline \multirow{2}{*}{ No } & \multirow{2}{*}{ Pertanyaan } & \multicolumn{2}{|c|}{ Frekuensi } & \multicolumn{2}{|c|}{ Persentase (\%) } \\
\hline & & Ya & Tidak & Ya & Tidak \\
\hline 1 & Apakah pembelajaran fisika menyenangkan? & 13 & 4 & 76,5 & 23,5 \\
\hline 2 & $\begin{array}{l}\text { Apakah dalam pembelajaran fisika guru menggunaknan bahan ajar } \\
\text { yang bervariasi? }\end{array}$ & 13 & 4 & 76,5 & 23,5 \\
\hline 3 & $\begin{array}{l}\text { Apakah bahan ajar yang digunakan guru fisika bersifat praktis dan } \\
\text { komunikatif? }\end{array}$ & 13 & 4 & 76,5 & 23,5 \\
\hline 4 & $\begin{array}{l}\text { Apakah bahan ajar yang digunakan guru dalam pembelajaran fisika } \\
\text { meningkatkan semangat belajar anda? }\end{array}$ & 8 & 9 & 47,1 & 52,9 \\
\hline 5 & $\begin{array}{l}\text { Apakah bahan ajar yang digunakan guru dalam mengajar membuat } \\
\text { anda lebih mudah memahami pelajaran fisika? }\end{array}$ & 12 & 5 & 70,6 & 29,4 \\
\hline 6 & $\begin{array}{l}\text { Apakah anda menyukai bahan ajar yang disusun sehingga } \\
\text { komunikatif dan memiliki ilustrasi gambar menarik? }\end{array}$ & 16 & 1 & 94,1 & 5,9 \\
\hline 7 & $\begin{array}{l}\text { Apakah dalam pembelajaran fisika, anda pernah menggunakan e- } \\
\text { modul? }\end{array}$ & 13 & 4 & 76,5 & 23,5 \\
\hline 8 & $\begin{array}{l}\text { Apakah e-modul yang digunakan dalam pembelajaran fisika } \\
\text { membosankan atau tidak menarik? }\end{array}$ & 5 & 12 & 29,4 & 70,6 \\
\hline 9 & $\begin{array}{l}\text { Apakah anda seang belajar fisika dengan menggunakan bahan ajar } \\
\text { e-modul? }\end{array}$ & 14 & 3 & 82,4 & 17,6 \\
\hline 10 & $\begin{array}{l}\text { Apakah anda menyukai pembelajaran fisika yang membuat anda } \\
\text { memprediksi, suatu fenomena dalam kehidupan sehari-hari? }\end{array}$ & 15 & 2 & 88,2 & 11,8 \\
\hline
\end{tabular}


11 Apakah anda menyukai pembelajaran fisika yang bersifat $\begin{array}{lllll}14 & 3 & 82,4 & \text { 17,6 }\end{array}$ mengobservasi suatu fenomena?

12 Apakah saat belajar materi teori kinetik gas guru menggunakan $\begin{array}{lllll}11 & 6 & 64,7 & 35,5\end{array}$ bahan ajar yang membosankan?

13 Apakah saat belajar materi teori kinetik gas model pembelajaran $\begin{array}{lllll}11 & 6 & 64,7 & 35,5\end{array}$ yang digunakan saat pembelajaran fisika kurang memudahkan anda memahami materi?

Tabel 2. Analisis angket siswa

\begin{tabular}{|c|c|}
\hline No & Analisis Pertanyaan \\
\hline 1 & $52,9 \%$ bahan ajar yang digunakan dalam pembelajaran fisika tidak meningkatkan semangat belajar siswa \\
\hline 2 & $82,4 \%$ siswa senang belajar fisika dengan menggunakan e-module \\
\hline 3 & $\begin{array}{l}94,1 \% \text { siswa juga menyukai bahan ajar yang disusun karena komunikatif dan memiliki ilustrasi gambar } \\
\text { yang menarik }\end{array}$ \\
\hline 4 & $\begin{array}{l}88,2 \% \text { siswa menyukai pembelajaran fisika yang membuat siswa memprediksi suatu fenomena } \\
\text { dikehidupan sehari-hari }\end{array}$ \\
\hline 5 & $82,4 \%$ siswa menyukai pembelajaran fisika yang bersifat mengobservasi suatu fenomena \\
\hline 6 & $\begin{array}{l}64,7 \% \text { siswa mengalami kesulitan memahami materi teori kinetik gas dengan model pembelajaran yang } \\
\text { digunakan guru saat pembelajaran }\end{array}$ \\
\hline
\end{tabular}

Analisis angket siswa (Tabel 2) dapat diketahui bahwa 52,9\% siswa menyatakan bahan ajar yang digunakan tidak meningkatkan semangat siswa dalam melakukan pembelajaran, khususnya dalam mempelajari materi Fisika. Menurut (Haryadi \& Nurmala, Pengembangan Bahan Ajar Fisika Kontekstual dalam Meningkatkan Motivasi Belajar Siswa, 2021) Proses belajar dalam pembelajaran tidak hanya sebatas menghafal dan memahami materi pembelajaran, tetapi juga memerlukan motivasi belajar agar siswa dapat memahami materi yang sedang dipelajarinya. Oleh karena itu, penyusunan bahan ajar perlu disusun secara menarik agar dapat membantu siswa dalam meningkatkan motivasi belajar. Hal ini diungkapkan oleh 94,1\% siswa yang menyatakan bahwa mereka menyukai bahan ajar yang disusun karena lebih komunikatif dan memiliki ilustrasi gambar yang menarik. Hal ini sejalan dengan penelitian (Susilawati \& Khoiri, Pengembangan Bahan Ajar Fisika Bermuatan Lifeskill Untuk Siswa SMA, 2014) yang menyatakan bahwa ilustrasi dan gambar yang menarik membantu siswa dalam memahami penjelasan konsep secara fisis. Selain itu, (Susilawati \& Khoiri, Pengembangan Bahan Ajar Fisika Bermuatan Lifeskill Untuk Siswa SMA, 2014) juga mengatakan tampilan yang menarik dan bahasa yang mudah dipahami sangat relevan dengan penyampaian materi. Didukung juga oleh pernyataan (Sitepu, 2012) bahwa ilustrasi mampu menimbulkan motivasi dan minat belajar, membantu siswa memahami materi dan konsep yang sulit dijelaskan oleh kata-kata, kemudian menarik perhatian siswa untuk belajar dan mampu membantu siswa mengingat materi pelajaran lebih lama.

\section{Simpulan}

Berdasarkan hasil dan diskusi diperoleh 1) 52,9\% bahan ajar yang digunakan dalam pembelajaran fisika tidak meningkatkan semangat belajar siswa; 2) 94,1\% siswa bahan ajar yang disusun sehingga komunikatif dan memiliki ilustrasi gambar yang menarik; 3) 64,7\% siswa mengalami kesulitan memahami materi teori kinetik gas dengan model pembelajaran digunakan guru saat pembelajaran; 4) dpembelajaran fisika yang membuat siswa memprediksi suatu fenomena dikehidupan sehari-hari $88,2 \%$ dan $84,2 \%$ m engobservasi suatu fenomena.

\section{Daftar Pustaka}

Haryadi, R., \& Nurmala, R. (2021). Pengembangan Bahan Ajar Fisika Kontekstual dalam Meningkatkan Motivasi Belajar Siswa. SPEKTRA: Jurnal Kajian Pendidikan Sains, 32-39. doi:http://dx.doi.org/10.32699/spektra.v7i1.168

Maslahah, W., \& Rofiah, L. (2019). Pengembangan Bahan Ajar (Modul) Sejarah Indonesia Berbasis Candi-candi di Blitar untuk Meningkatkan Kesadaran Sejarah. Jurnal Agastya, 32-43. doi:http://doi.org/10.25273/ajsp.v9i1.3418 
Masrizal, M. (2012). Mix Method Research. Jurnal kesehatan Masyarakat Andalas, 53-56. doi:https://doi.org/10.24893/jkma.v6i2.89

Mustafa, P. S. (2020). Kontribusi Kurikulum Pendidikan Jasmani, Olahraga, dan Kesehatan di Indonesia dalam Membentuk Keterampilan Era Abad 21. Jurnal Pendidikan : Riset dan Konseptual, III(2), 437-452. doi:https://doi.org/10.28926/riset_konseptual.v4i3.248

Olayinka, A.-R. B. (2016). Effects of Intructional Materials on Secondary Schools Students' Academic Achievement in Social Studies in Ekiti State, Nigeria. World Journal of Education, 32-39. doi:https://doi.org/10.5430/wje.v6n1p32

Rahman, A. S. (2016). Pengembangan Modul Kimia Berbasis POE (Predict, Observe, Explain) pada Materi Koloid. 1-8.

Rukajat, A. (2018). Pendekatan Penelitian Kuantitatif: Quantutative Research Approach. Yogyakarta: CV Budi Utomo.

Safitri, E. (2019). Pengaruh Model POE Terhadap Hasil Belajar IPA Fisika Siswa SMP. jurnal pendidikan fisika dan teknologi, 5, 197-204. doi:http://dx.doi.org/10.29303/jpft.v5i2.825

Sidiq, R., \& Najuah. (2020). Pengembangan E-Modul Interaktif Berbasis Android pada Mata Kuliah Strategi Belajar Mengajar. jurnal pendidikan sejarah, 9, 1-14. doi:https://doi.org/10.21009/JPS.091.01

Sitepu, B. P. (2012). Penulisan Buku Teks Pelajaran. Bandung: PT. Remaja Rosdakarya.

Solihudin, T. (2018). Pengembangan E-Modul Berbasis Web untuk Meningkatkan Pencapaian Kompetensi Pengetahuan Fisika pada Materi Listrik Statis dan Dinamis SMA. Jurnal wahana pendidikan fisika, 3, 51-56. doi:https://doi.org/10.17509/wapfi.v3i2.13731

Susilawati, \& Khoiri, N. (2014). Pengembangan Bahan Ajar Fisika Bermuatan Lifeskill Untuk Siswa SMA. Jurnal Riset dan Kajian Pendidikan Fisika, 86-89. doi:http://dx.doi.org/10.12928/jrkpf.v1i2.1998

Tania, 1., \& joni, s. (2017). Pengembangan Bahan Ajar E-Modul Sebagai Pendukung Pembelajaran Kurikulum 2013 Pada Materi Ayat Jurnal Penyesuaian Perusahaan Jasa Siswa Kelas X Akutansi SMK Negeri 1 Surabaya. jurnal pendidikan akutansi, 5, 1-9.

Varonika, I. K., Santyadiputra, G. S., \& Sindu, I. G. (2016). Pengembangan E-Modul Berbasis Project Based Learning pada Mata Pelajaran Sistem Operasi Jaringan Kelas XI di SMK Negeri 3 Singraja. Jurnal Pendidikan Teknologi dan Kejuruan, 212-224. doi:http://dx.doi.org/10.23887/jptk-undiksha.v13i2.8529

Yupani, Garminah, \& Mahadewi. (2013). Pengaruh Model Pembelajaran Predict-Observe-Explain (POE) Berbantuan Materi Bermuatan Kearifan Lokal Terhadap Hasil Belajar IPA Siswa Kelas IV. Mimbar PGSD Undiksha. doi:http://dx.doi.org/10.23887/jjpgsd.v1i1.1363 